\title{
An outcome analysis of videoscopic assisted retroperitoneal debridement in infected pancreatic necrosis: a single centre experience
}

\author{
Dattaraj Budkule ${ }^{1}$, Gunjan Desai ${ }^{1}$, Prasad Pande ${ }^{1}$, Rajvilas Narkhede ${ }^{1}$, Prasad Wagle ${ }^{1}$, Paresh Varty ${ }^{1}$ \\ ${ }^{1}$ Clinic of General Surgery and Surgical Gastroenterology, Lilavati Hospital and Research Centre, Mumbai, India
}

\begin{abstract}
Objective: Infected pancreatic necrosis (IPN) is a dreadful complication of moderately severe and severe acute necrotising pancreatitis (ANP). Videoscopic assisted retroperitoneal debridement (VARD) is a minimally invasive surgical option for predominantly left sided, posterior and laterally located disease in patients not responding to conservative and percutaneous options. This study aimed to present an outcome analysis of VARD in the management of IPN at our tertiary care centre.

Material and Methods: The present retrospective analysis of prospectively entered data included 22 patients diagnosed as ANP with IPN from January 2015 to December 2017. These patients were admitted in the surgical gastroenterology unit of our tertiary care centre. The outcome of these patients managed with VARD was evaluated.

Results: The aetiology of ANP was idiopathic, and gallstones were found in 7 patients each and alcohol in 8 . Twelve patients were managed with a single VARD procedure; whereas, 10 required a re-debridement due to suboptimal improvement. Eighteen out of 22 patients survived whereas 4 succumbed to major postoperative bleeding/severe sepsis and multiorgan failure (Mortality 18.2\%). Hospital stay after the index procedure was between 6 to 11 weeks.

Conclusion: VARD is a safe and effective surgical option for the management of IPN that worsens or fails to respond to conservative and percutaneous drainage options after a minimum of 4 weeks of moderately severe and severe ANP. It decreases postoperative morbidity and mortality and avoids major laparotomy, and hence, it can be considered in a selected group of patients.
\end{abstract}

Keywords: Videoscopic assisted retroperitoneal debridement, acute necrotising pancreatitis, infected pancreatic necrosis, step up approach

Cite this article as: Budkule D, Desai G, Pande P, Narkhede $R$, Wagle P, Varty P. An outcome analysis of videoscopic assisted retroperitoneal debridement in infected pancreatic necrosis: a single centre experience. Turk J Surg 2019; 35 (3): 214-222.

\section{Corresponding Author} Dattaraj Budkule

E-mail: dbudkule9@gmail.com

Received: 15.08 .2018

Accepted: 10.10 .2018

Available Online Date: 23.09.2019

(c) Copyright 2019 by Turkish Surgical Society Available online at www.turkjsurg.com

DOI: $10.5578 /$ turkjsurg.4289

\section{INTRODUCTION}

Infected pancreatic necrosis (IPN) is one of the most feared complications occurring in approximately $8-12 \%$ of patients with moderately severe and severe acute pancreatitis, leading to increased morbidity and mortality $(1,2)$. 'Step up approach' for the treatment of IPN has been a paradigm shift in its management (3). Videoscopic assisted retroperitoneal debridement (VARD) is one of the minimally invasive surgical options in the step up approach, used for predominantly left sided, posterior and laterally located disease in patients not responding to conservative, endoscopic and/or percutaneous options (3). The present study analyzes our indications, techniques and outcomes of VARD in the management of moderately severe and severe acute necrotising pancreatitis (ANP) with IPN and provides a brief review of current literature.

\section{MATERIAL and METHODS}

The study was performed after the approval of research protocols by the institutional ethics committee in accordance with international agreements (World Medical Association Declaration of Helsinki "Ethical Principles for Medical Research Involving Human Subjects," amended in October 2013, www.wma.net)

This observational study is a retrospective evaluation of prospectively entered data of 22 patients admitted with moderately severe and severe ANP with IPN who were managed with VARD from January 2015 to December 2017 in the surgical gastroenterology unit of our tertiary care centre. Severity was assessed as per the 2012 revision of Atlanta classification with modified Marshall scoring system for organ 
dysfunction. ANP was defined as inflammation associated with pancreatic parenchymal and/or peripancreatic necrosis. Moderately severe acute pancreatitis was defined as transient organ failure ( $<48$ hours) and/or local or systemic complications; whereas severe acute pancreatitis was defined as persistent (> 48 hours) organ failure (single/multiple) (3). IPN was diagnosed by the presence of clinical features of sepsis/ air foci on contrast enhanced computed tomography (CECT) abdomen or positive cultures in percutaneously drained collections.

The data was retrieved with regards to patient's demographic profile, etiology, site of necrosum, duration of conservative treatment, drainage, number of VARD procedures done, morbidity, hospital stay and outcome. The patients were evaluated by CECT abdomen at approximately 1 week from the onset of symptoms and on demand during the hospital stay. Our approach to the management of this patient group is as shown in the algorithm (Figure 1).

VARD was decided upon after the patients failed to improve or deteriorated (persistent or worsening of multiorgan failure, sepsis, CECT evidence of persistent necrosum) at least 4 weeks after the onset of ANP in spite of treatment with intravenous antibiotics, maximised supportive care in the intensive care unit and percutaneous catheter drainage. In all patients, a $12 \mathrm{Fr}$ catheter was placed percutaneously from the left posterior subcostal approach in the necrotic cavity under computed tomography guidance at least 48 hours prior to VARD procedure.

VARD was then performed with the patient in supine position, under general anaesthesia with the left side elevated by 30 degrees. The representative image of IPN on CECT as shown in was studied and a guided $5 \mathrm{~cm}$ left subcostal incision was taken (Figure 2 and 3). The dissection was deepened along the percutaneous catheter until necrotic material was visualised. Gross solid necrotic material was removed under direct vision (Figure 4). $\mathrm{A} 0^{\circ}$ laparoscope was then introduced into the cavity and air insufflated, if required, after temporarily closing the sheath (Figure 5). The remaining necrotic material was then removed under videoscopic guidance and a thorough normal saline wash was given to remove the loose necrosum (Figure 6). Two drains were left in the cavity, 1 superficial and 1 deep, for irrigation and drainage. The patients were taken to the intensive care unit (ICU) after the procedure, and antibiotics, enteral feeding and supportive care were continued. Postoperative lavage 6 litres/day was given with normal saline until the draining fluid was clear. Postoperative hospital course was recorded for the need of repeat VARD or other surgical/endoscopic/percutaneous interventional radiology procedures, postoperative complications, duration of hospital stay, bowel function and management of patient till discharge. All patients were discharged with drains after check CECT scans which also guided drain removal. The patients were followed up at 1 month and 3 months after discharge and then as required. The representative image of one such patient who had undergone
VARD followed by repeat procedure via laparoscopic transperitoneal transmesocolic approach is as depicted in Figure 7.

The complications were defined as follows: Postoperative pancreatic fistula (POPF) was defined as per international study group of pancreatic surgery (ISGPS) as drain output of any measurable volume of fluid with an amylase level $>3$ times the upper limit of normal serum amylase, associated with a clinically relevant development/condition related directly to the postoperative pancreatic fistula (4). Superficial incisional, deep incisional and organ space surgical site infections were defined according to the 1992 modified definitions of nosocomial surgical site infection by centre for disease control (CDC) (5). Paralytic ileus was defined as hypomotility of the gastrointestinal (GI) tract in the absence of mechanical bowel obstruction for more than 3 days following the procedure (6). Hemorrhagic complications were divided into intraluminal gastrointestinal haemorrhage or intraabdominal haemorrhage (7). Postoperative course, complications and their management protocol in our department is as shown in Figure 8. All the data was tabulated and analysed.

\section{RESULTS}

The demographic data of the 22 patients who underwent VARD is listed in Table 1. Mean age of the patients was 48.6 years, 16 of which were male. Mean body mass index was 27.8 . Nine patients had diabetes mellitus; whereas, 7 had hypertension. Aetiology was alcohol (8), gall stones (7) and idiopathic (7). All 22 patients had moderately severe or severe acute necrotising pancreatitis. All patients had pancreatic and peripancreatic necroses with minimal fluid documented on CECT scan. Prior CT guided percutaneous catheter drainage was done in all the patients.

The time from diagnosis of ANP to VARD ranged from 32 to 35 days. All patients had a subcostal retroperitoneal approach during the first VARD procedure. 10 patients required a repeat VARD procedure on account of CECT abdomen showing residual or newly formed collection or worsening organ failure. Out of these 10 patients, 5 required one more procedure in the form of laparoscopic (3) or open (2) transperitoneal transmesocolic drainage for central necrotic collection which persisted after the second VARD procedure. Hospital stay after the index procedure was between 6 to 11 weeks.

Thirty two postoperative complications with 4 fatalities were observed, of which 13 were minor and 19 were major complications. Four patients had massive bleeding postoperatively, 3 from a branch of splenic artery and 1 from the gastroduodenal artery. Angioembolisation was done postoperatively and although the bleeding was controlled in these 4 patients, they succumbed to hypovolemia/ongoing sepsis and multiorgan failure. All of these 4 patients had undergone repeat VARD procedures. Nine patients developed superficial surgical site infections whereas 4 developed paralytic ileus. 
Acute necrotizing pancreatitis

[Revised Atlanta classification 2012]

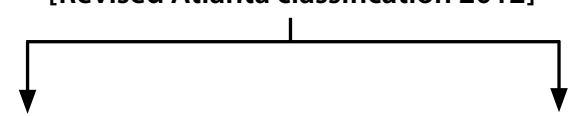

Mild acute pancreatitis

Not included in this analysis

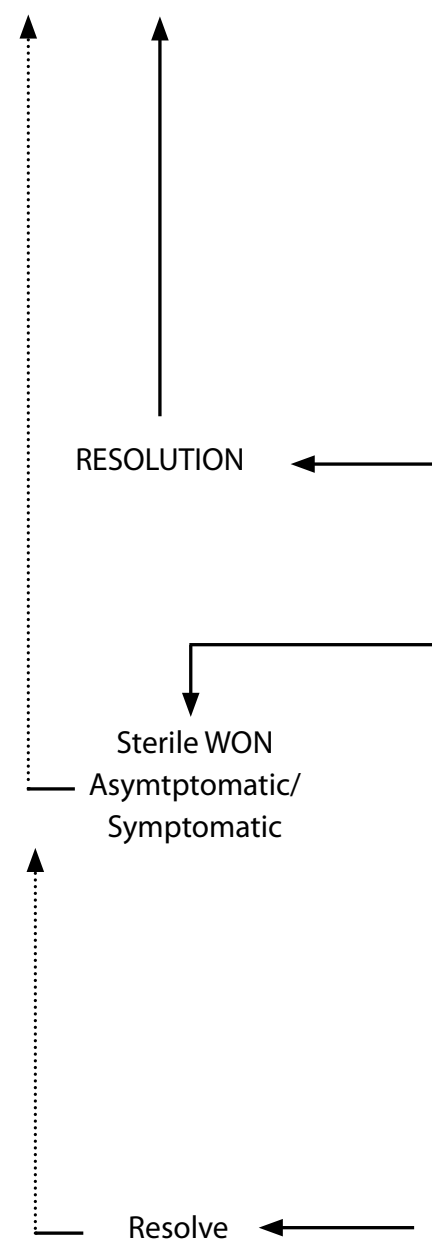

Moderately severe/Severe acute pancreatitis

CONSERVATIVE MANAGEMENT

- Nasojejunal feeds

- \pm Paranteral nutrition

- Organ Support/Intestive care

- Antibiotics \{For clinical/Imaging evidence of infection in Acute necrotic collection/Acute peripancreatic fluid collection or other focus of infection: Chest, line sepsis, urinary tract infection.
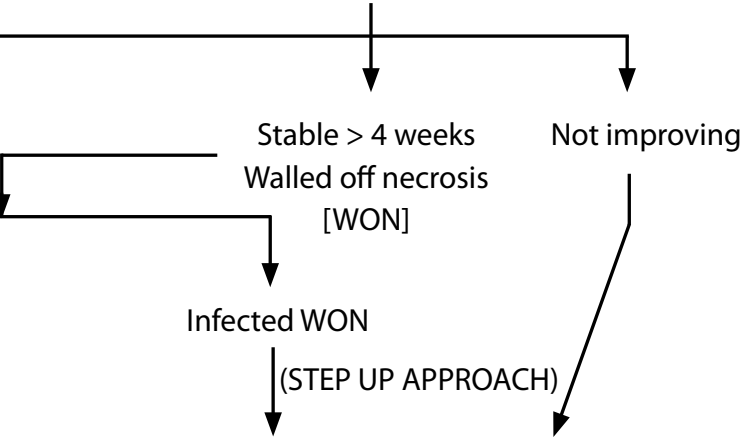

Access for percutaneous retroperitoenal drainage present

Wall diameter $<5 \mathrm{~mm}$ [ Not amenable

to internal drainage]

Location in body and tail region

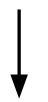

Percutaneous retroperitoneal drainage

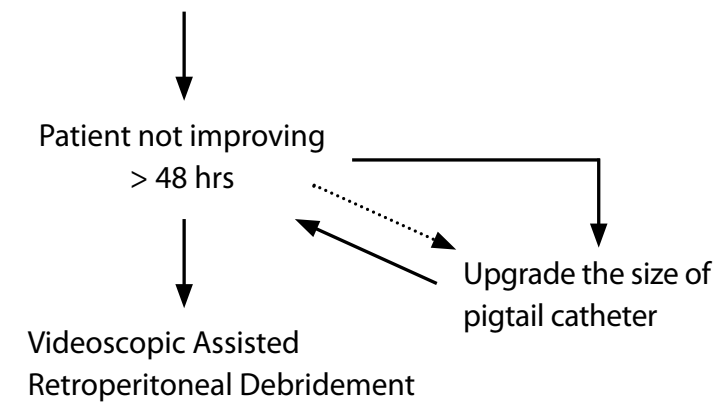

Figure 1. Algorithm showing our approach to the management of moderately severe and severe acute necrotising pancreatitis as well as patient selection for videoscopic assisted retroperitoneal debridement. 


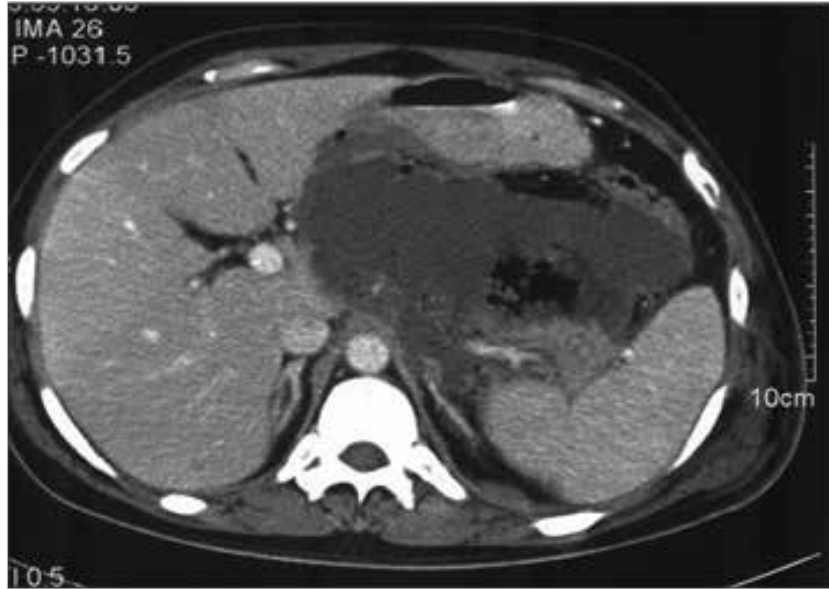

Figure 2. Representative image of infected pancreatic necrosis on contrast enhanced computed tomography.

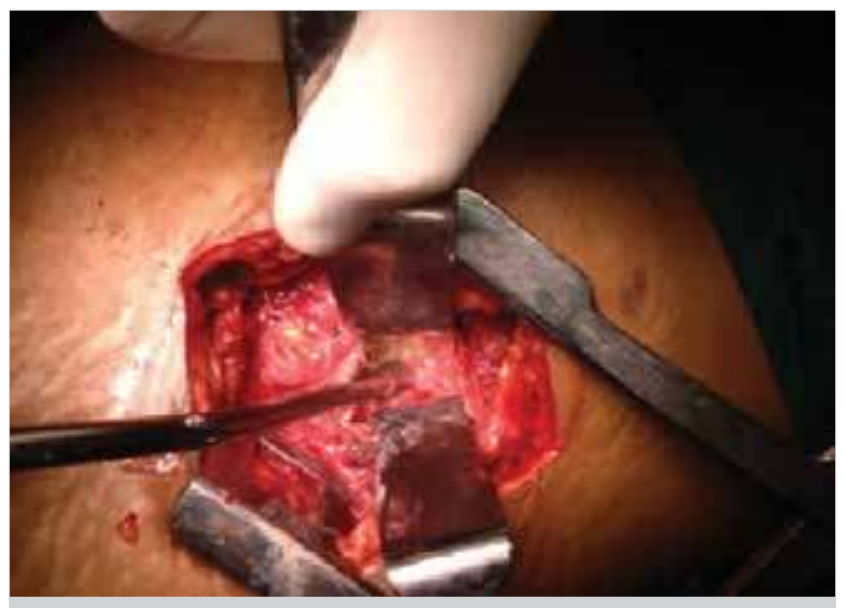

Figure $3.5 \mathrm{~cm}$ left subcostal incision.

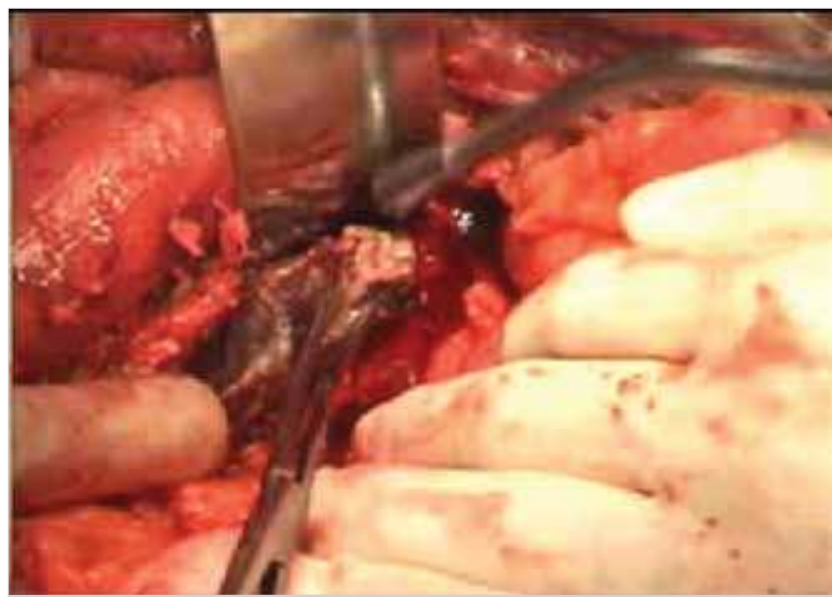

Figure 4. Gross solid necrotic material being removed under direct vision.

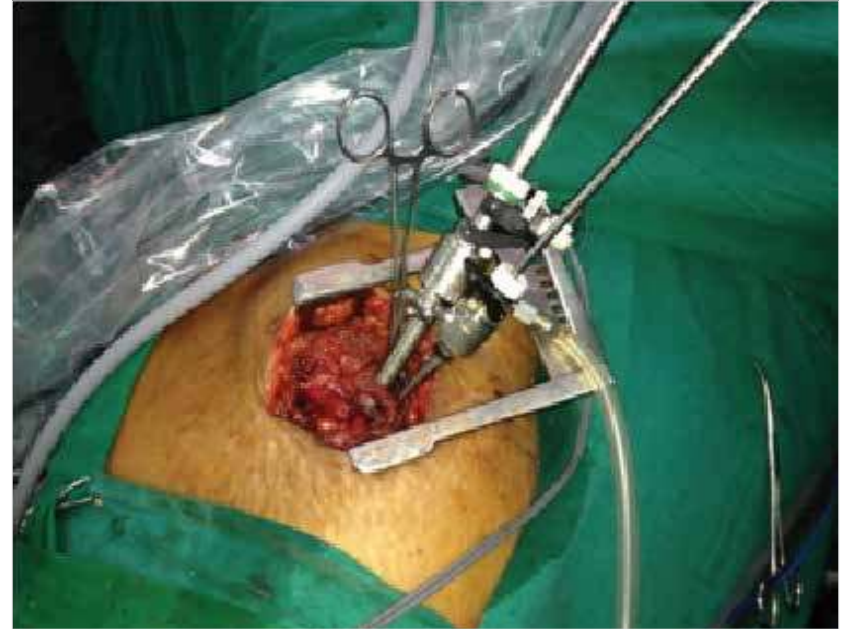

Figure $5.0^{\circ}$ laparoscope introduced into the retroperitoneum.

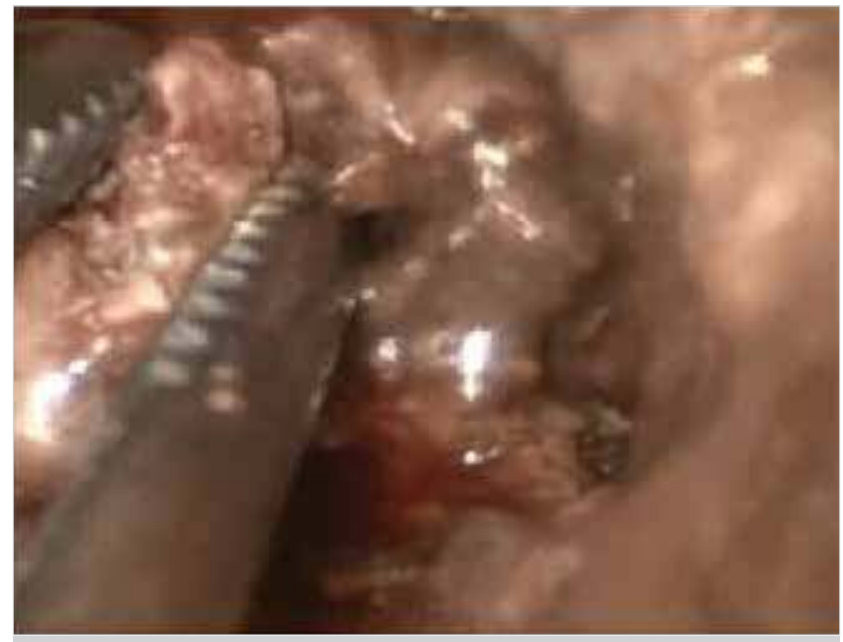

Figure 6. Necrotic material being removed under laparoscopic guidance.

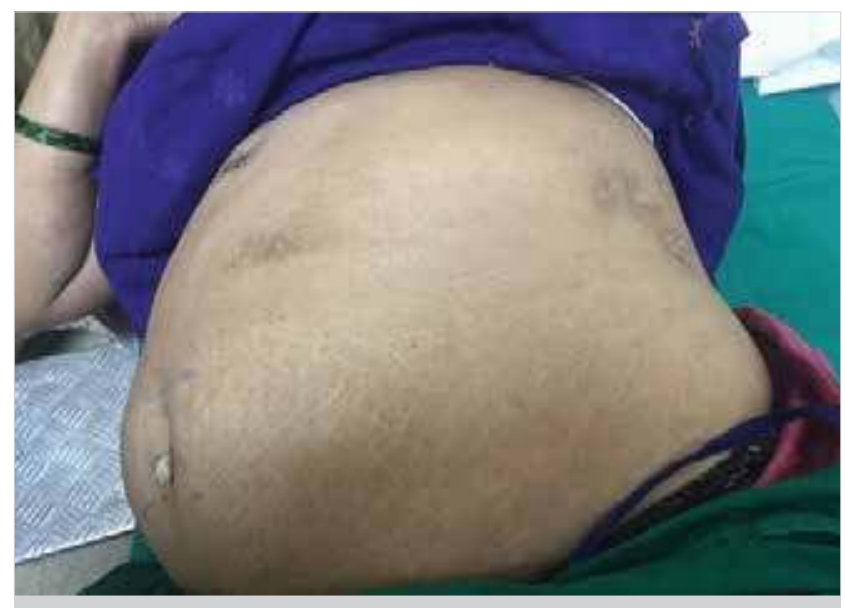

Figure 7. Final postoperative picture with healed incisions. 


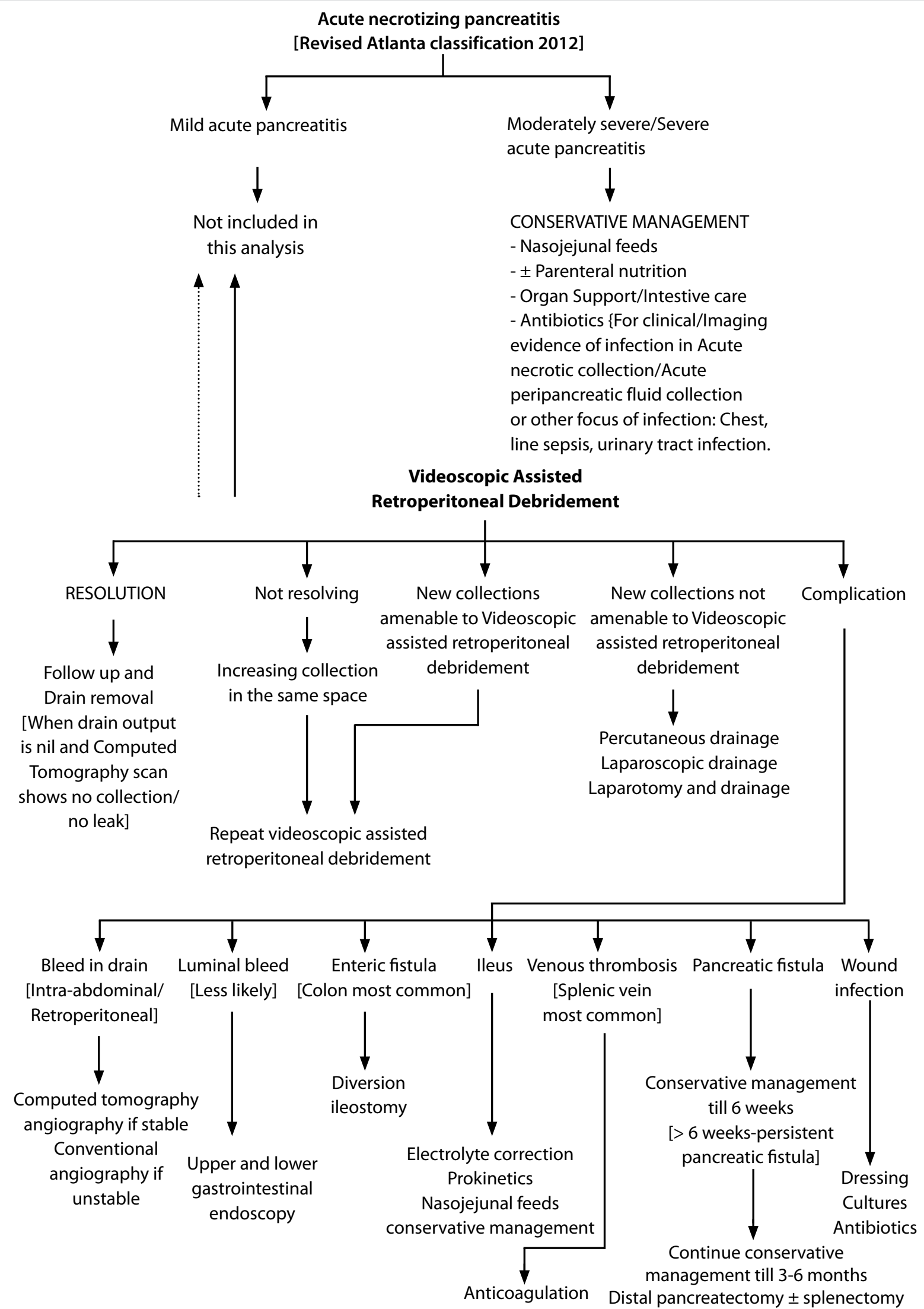


Table 1. Patient characteristics, etiology, disease details, treatment details, outcome

\section{Patient characteristics}

Median age and range (years)

Sex (Male/Female)

Mean Body mass index (BMI)

\section{Co morbid conditions}

Diabetes mellitus

Hypertension

\section{Aetiology of pancreatitis}

Alcohol

Gallstones

Idiopathic

\section{Site of necrosis \\ Body \\ Tail}

\section{Duration of conservative treatment prior to VARD}

Mean (Range \{in days\})

\section{VARD attempts}

1

2

In patient stay

Mean (Range \{in days\})

\section{Post op complications}

Failure to resolve after first attempt

Surgical site infection

Bleeding from splenic artery

Bleeding from gastroduodenal artery

Paralytic ileus

Post operative pancreatic fistula

Colonic fistula

\section{Mortality}

WARD: Videoscopic assisted retroperitoneal debridement.

Of the 18 patients that survived, 4 developed Grade C postoperative pancreatic fistula which were managed by Roux en $Y$ fistulojejunostomy in 2 and distal pancreatectomy in 2 after 6 months of expectant management. In the remaining 14 patients, drain output gradually diminished and drains were removed after a follow up CECT scan. One patient developed colonic fistula which was managed by diversion loop ileostomy.

\section{DISCUSSION}

ANP occurs in 5-10\% cases of acute pancreatitis (8). Of these, moderately severe and severe acute pancreatitis (SAP) are life threatening conditions associated with high mortality and morbidity (5). The presence of IPN further doubles mortality in SAP (9).

Conventional surgical intervention by open or laparoscopic necrosectomy for IPN is associated with a mortality rate of $25 \%$ to $40 \%$ (10). The open approach is also associated with relatively higher rates of complications such as bleeding (1-23\%), colonic fistula (1-17\%) and pancreatic fistula (3-72\%) (11). A systematic review by Nieuwenhuijs et al. has concluded that the mortality rates of ANP treated with open abdominal surgery with continuous postoperative lavage remains high, mainly due to multiorgan failure despite optimal surgical and medical treatment. (12) Shifting to VARD as a treatment option might help decrease the morbidity and mortality associated with these open surgeries $(13,14)$. Connor et al. have also proposed that minimally invasive retroperitoneal necrosectomy is a new technique that has shown promising results, and could be preferable to open pancreatic necrosectomy in selected patients (15).

The PANTER trial has shown that a minimally invasive step up approach, as compared with open necrosectomy, reduces the rate of the composite end point of major complications or de- 
ath among patients with necrotising pancreatitis and infected necrotic tissue (16). Thus, less invasive options such as percutaneous drainage, endoscopic transgastric and laparoscopic transperitoneal necrosectomy have been applied for this indication (9). We also prefer the step up approach at our centre, depending on the location of the necrosum, route of access and local expertise.

The percutaneous endoscopic approaches for necrosectomy were described in the early part of the $21^{\text {st }}$ century, but were associated with many drawbacks viz: time consuming, multiple interventions, incomplete necrosectomy and bleeding $(17,18)$. Carter et al. have proposed that minimally invasive approach for pancreatic necrosectomy has encouraging results but needs further evaluation with larger studies (19). VARD has thus evolved as a result of allowing minimal invasive approach to drain infected pancreatic necrosis without removing the entire solid necrosum in a "step up fashion" (20). VARD can be considered as a hybrid between open necrosectomy and a percutaneous endoscopic approach (1).

VARD is done in cases of established infected pancreatic necrosis after giving a maximised trial of conservative management with intravenous antibiotics, organ support [respiratory, vasopressor, dialysis], and percutaneous drainage techniques (21). Radiological evidence of walled off pancreatic necrosis [WOPN] is essential to plan this minimally invasive procedure (1). The technique involves the placement of a 12-14 french percutaneous catheter in the necrotic cavity through the left retroperitoneum 24-48 hours prior to the VARD procedure. During the procedure, through a small left subcostal incision, the necrotic cavity is reached by following the percutaneous catheter and solid but loose necrosum is removed under vision. This is followed by the insertion of $0^{\circ}$ laparoscope and carbon dioxide gas inflated for better vision. The loosely adherent necrosum is further removed, thorough wash given and 2 drains kept (superficial and deep) for postoperative lavage (13).

Variations in the technique described in the literature include variations in the size of incisions, ranging from sinus tract endoscopy to as big as $15 \mathrm{~cm}$ translumbar incisions. Also the use of wide range of videoscopes such as laparoscope, nephroscope, cystoscope, mediastinoscope have been described (18). There are wide variations in approach to the necrosum, postoperative operative lavage fluids as well as their volumes infused per day $(14,16)$.

VARD provides an excellent alternative to necrosectomy by laparotomy. Our early results on a few patients as described are comparable to those reported in the literature (9). Horvath et al. have evaluated the safety and efficacy of VARD for IPN in 40 patients using a multicentre, prospective, single arm phase 2 study and concluded that VARD is safe as well as efficacious for
IPN (7). Most published data regarding minimally invasive necrosectomy have a postoperative hospital stay ranging between 50 and 64 days which are comparable to our study (17). Reintervention rates for further necrosectomy may be needed in as high as $73 \%$ whereas in our study it was $45.5 \%$ (17). The rates of individual complications viz infection, bleeding, fistula as well as mortality were comparable to our study (18.2\%) (22). Overall morbidity in different studies has shown wide variation from 0 to $93 \%$ and mortality ranging from 10 to $27 \%$. (3) Other studies have shown postoperative bleeding rates (7.5\%) compared to ours (18.2\%) and similar pancreatic fistula rates (18.2\%) (3). Interestingly, our enteric fistula rate (4.5\%) was less as compared to others $(23,24)$.

The advantages of VARD include less perioperative stress on an already sick patient, benefit of both limited open and laparoscopic approach, simplicity and cost effectiveness, the disadvantage being the need of undergoing multiple repeat procedures. Also, life-threatening complications are still possible, necessitating close vigilance by a multispecialty team in an intensive care setting.

\section{Study Limitations}

The limitations of our study were the relatively small sample size, single centre data and that there were no comparative group of patients.

\section{CONCLUSION}

VARD is a safe and effective surgical option for the management of IPN that worsens or fails to respond to conservative and percutaneous drainage options. Necrosum is debrided and drained using a hybrid open - laparoscopic approach alongside the percutaneously placed catheter. It decreases postoperative morbidity and mortality and avoids major laparotomies and hence, should be considered in the management of this selected group of patients.

Ethics Committee Approval: The study was performed after the approval of research protocols by the institutional ethics committee in accordance with international agreements (World Medical Association Declaration of Helsinki "Ethical Principles for Medical Research Involving Human Subjects," amended in October 2013, www.wma.net)

Informed Consent: Written informed consent was obtained from all patients involved in the study.

Peer-review: Externally peer-reviewed.

Author Contributions: Concept - P.W., P.V.; Design - P.W., P.V.; Supervision G.D., P.P., R.N., P.W., P.V.; Materials - P.W., P.V.; Data Collection and/or Processing - D.B.; Analysis and/or Interpretation - D.B.; Literature Search - D.B.; Writing Manuscript - D.B.; Critical Reviews - G.D., P.P., R.N., P.W., P.V.

Conflict of Interest: No conflict of interest was declared by the authors.

Financial Disclosure: The authors declared that this study has received no financial support. 


\section{REFERENCES}

1. Lim E, Sundaraamoorthy RS, Tan D, Teh HS, Tan TJ, Cheng A. Step-up approach and video assisted retroperitoneal debridement in infected necrotizing pancreatitis: A case complicated by retroperitoneal bleeding and colonic fistula. Ann Med Surg (Lond) 2015; 4: 225-9. [CrossRef]

2. Ji L, LV JC, Song ZF, Jiang MT, Li L, Sun B. Risk factors of infected pancreatic necrosis secondary to severe acute pancreatitis. Hepatobiliary Pancreat Dis Int 2016; 15: 428-33. [CrossRef]

3. Breasted JH ETESSPC, Illinois: The University Chicago Press, 1930; Special edition, 1984.

4. Bassi C, Marchegiani G, Dervenis C, Sarr M, Abu Hilal M, Adham M, et al. The 2016 update of the International Study Group (ISGPS) definition and grading of postoperative pancreatic fistula: 11 years after. Surgery 2017; 161: 584-91. [CrossRef]

5. Horan TC, Gaynes RP, Martone WJ, Jarvis WR, Emori TG. CDC definitions of nosocomial surgical site infections, 1992: a modification of CDC definitions of surgical wound infections. Infect Control Hosp Epidemiol 1992; 13: 606-8. [CrossRef]

6. Livingston EH, Passaro EP, Jr. Postoperative ileus. Dig Dis Sci 1990; 35: 121-32. [CrossRef]

7. Sharma PK, Madan K, Garg PK. Hemorrhage in acute pancreatitis: should gastrointestinal bleeding be considered an organ failure? Pancreas 2008; 36: 141-5. [CrossRef]

8. Jagielski M, Smoczynski M, Adrych K. Endoscopic treatment of multilocular walled-off pancreatic necrosis with the multiple transluminal gateway technique. Wideochir Inne Tech Maloinwazyjne 2017; 12: 199-205. [CrossRef]

9. Sorrentino L, Chiara O, Mutignani M, Sammartano F, Brioschi P, Cimbanassi S. Combined totally mini-invasive approach in necrotizing pancreatitis: a case report and systematic literature review. World J Emerg Surg 2017;12:16. [CrossRef]

10. Senthil Kumar P, Ravichandran P, Jeswanth S. Case matched comparison study of the necrosectomy by retroperitoneal approach with transperitoneal approach for necrotizing pancreatitis in patients with CT severity score of 7 and above. Int J Surg 2012; 10: 587-92. [CrossRef]

11. Connor S, Alexakis N, Raraty MG, Ghaneh P, Evans J, Hughes M, et al. Early and late complications after pancreatic necrosectomy. Surgery 2005; 137: 499-505. [CrossRef]

12. Nieuwenhuijs VB, Besselink MG, van Minnen LP, Gooszen HG. Surgical management of acute necrotizing pancreatitis: a 13-year experience and a systematic review. Scand J Gastroenterol Suppl 2003; 38: 111-6. [CrossRef]
13. Ulagendra Perumal S, Pillai SA, Perumal S, Sathyanesan J, Palaniappan R. Outcome of video-assisted translumbar retroperitoneal necrosectomy and closed lavage for severe necrotizing pancreatitis. ANZ J Surg 2014; 84: 270-4. [CrossRef]

14. Dash NR, Samantaray SP, Garg P, Gamanagatti S, Pal S, Sahni P, et al. Retroperitoneal laparoscopy for pancreatic necrosis. International Journal of Science and Research (IJSR) 2017;6:1069-74.

15. Connor S, Ghaneh P, Raraty M, Sutton R, Rosso E, Garvey CJ, et al. Minimally invasive retroperitoneal pancreatic necrosectomy. Dig Surg 2003; 20:270-7. [CrossRef]

16. 16. van Santvoort HC, Besselink MG, Cirkel GA, Gooszen HG. [A nationwide Dutch study into the optimal treatment of patients with infected necrotising pancreatitis: the PANTER trial]. Ned Tijdschr Geneeskd 2006; 150: 1844-6.

17. Thompson CC, Kumar N, Slattery J, Clancy TE, Ryan MB, Ryou M, et al. A standardized method for endoscopic necrosectomy improves complication and mortality rates. Pancreatology 2016; 16: 66-72. [CrossRef]

18. van Santvoort HC, Besselink MG, Horvath KD, Sinanan MN, Bollen $T L$, van Ramshorst B, et al. Videoscopic assisted retroperitoneal debridement in infected necrotizing pancreatitis. HPB (Oxford) 2007; 9: 156-9. [CrossRef]

19. Carter CR, McKay CJ, Imrie CW. Percutaneous necrosectomy and sinüs tract endoscopy in the management of infected pancreatic necrosis: an initial experience. Ann Surg 2000; 232: 175-80. [CrossRef]

20. Rohan Jeyarajah D, Osman HG, Patel S. Advances in management of pancreatic necrosis. Curr Probl Surg 2014; 51: 374-408. [CrossRef]

21. Zerem E. Treatment of severe acute pancreatitis and its complications. World J Gastroenterol 2014; 20: 13879-92. [CrossRef]

22. Horvath KD, Kao LS, Wherry KL, Pellegrini $C A$, Sinanan MN. A technique for laparoscopic-assisted percutaneous drainage of infected pancreatic necrosis and pancreatic abscess. Surg Endosc 2001; 15: 1221-5. [CrossRef]

23. van Brunschot S, van Grinsven J, van Santvoort HC, Bakker OJ, Besselink MG, Boermeester MA, et al. Endoscopic or surgical step-up approach for infected necrotising pancreatitis: a multicentre randomised trial. Lancet 2018; 391: 51-8.

24. Horvath K, Freeny P, Escallon J, Heagerty P, Comstock B, Glickerman $D J$, et al. Safety and efficacy of video-assisted retroperitoneal debridement for infected pancreatic collections: a multicenter, prospective, single-arm phase 2 study. Arch Surg 2010; 145: 817-25. [CrossRef] 


\section{ORIJINAL ÇALIŞMA-ÖZET}

Turk J Surg 2019; 35 (3): 214-222

\section{Enfekte pankreatik nekrozda videoskopik yardımlı retroperitoneal debridmanın sonuç analizi: tek merkezli çalışma}

Dattaraj Budkule ${ }^{1}$, Gunjan Desai ${ }^{1}$, Prasad Pande ${ }^{1}$, Rajvilas Narkhede ${ }^{1}$, Prasad Wagle ${ }^{1}$, Paresh Varty ${ }^{1}$

${ }^{1}$ Lilavati Hastanesi Araştırma Merkezi, Genel Cerrahi ve Gastroenteroloji Cerrahisi Kliniği, Mumbai, Hindistan

\section{ÖZET}

Giriş ve Amaç: Enfekte pankreatik nekroz (EPN), orta derecede şiddetli ve şiddetli akut nekrotizan pankreatit (ANP)'in korkutucu komplikasyonudur. Videoskopik yardımlı retroperitoneal debridman (VYRD), konservatif ve perkütan seçeneklere yanıt vermeyen hastalarda ağırlıklı olarak sol taraflı, posterior ve lateral yerleşimli hastalık için minimal invaziv bir cerrahi seçenektir. Bu çalışmanın amacı, üçüncü basamak tedavi merkezimizde EPN yönetiminde kullanılan VRYD'nin sonuç analizini sunmaktı.

Gereç ve Yöntem: Prospektif olarak girilen verilerin retrospektif analizini içeren bu çalışmaya Ocak 2015 ve Aralık 2017 tarihleri arasında EPN'li ANP tanısı alan 22 hasta dahil edildi. Bu hastalar üçüncü basamak tedavi merkezimizin cerrahi gastroenteroloji bölümüne yatırıldı. VYRD ile tedavileri yapılan hastalardan alınan sonuçlar değerlendirmeye tabi tutuldu.

Bulgular: ANP etyolojisi yedi hastada idiyopatik olmakla birlikte yedi hastada safra kesesi taşı ve sekiz hastada alkol kaynaklıydı. On iki hasta tek bir VRYD müdahalesi ile tedavi edilirken 10 hastada yetersiz iyileşme sebebiyle ikinci debridmana gerek duyuldu. Yirmi iki hastadan $18^{\prime i}$ kurtulurken dört hastada majör postoperatif kanama/şiddetli sepsis ve çoklu organ yetmezliği gelişti (mortalite: \%18.2). Hastanede yatış süresi 6-10 hafta arasındaydı.

Sonuç: Dört hafta süren orta şiddetli veya şiddetli ANP sonrasında konservatif ve perkütan drenaj seçeneklerine yanıt vermeyen veya daha da kötüleşen EPN tedavisinde VRYD güvenilir ve efektif bir cerrahi seçenektir. Postoperatif morbidite ve mortaliteyi azaltıp majör laparotomi ihtimalinin önüne geçtiği için seçilmiş hasta gruplarında göz önünde bulundurulabilir.

Anahtar Kelimeler: Videoskopik yardımlı retroperitoneal debridman, akut nekrotizan pankreatit, enfekte pankreatik nekroz, step up yaklaşımı

Doi: $10.5578 /$ turkjsurg.4289 